\title{
TINJAUAN TERHADAP PRINSIP-PRINSIP PENGAJARAN ANAK BERDASARKAN ULANGAN 6:1-19
}

\author{
Oleh : Dr. Ninik Tri Utami, M.Pd.K \\ Sekretaris Prodi Magister Pendidikan Agama Kristen
}

\begin{abstract}
ABSTRAK
Pengakuan akan keesaan Allah adalah keharusan bagi umat Allah. Ini adalah pengakuan iman yang amat besar. Pengakuan akan keesaan Allah diwujudnyatakan dalam ketaatan. Sebagai dasar dari hidup dalam ketaatan adalah kesediaan mendengarkan firman dan melakukannya. Pengakuan akan keesaan Allah adalah keharusan bagi umat Allah pada waktu itu. Hal ini diajarkan pada waktu umat itu masih anak-anak. Keharusan bagi anak-anak untuk menghafalkan dan setelah itu memahami. Kewajiban bagi setiap umat Alah untuk mengucapkan pengakuan itu. Sejak masih kecil umat Allah sudah harus wajib mempelajarinya dan kehidupan seperti mendatangkan berkat-berkat Allah dalam kehidupan selanjutnya. Prinsip mengasihi Allah adalah prinsip utama yang ditekankan dalam kehidupan umat Allah. Menekankan sikap hati yang mengasihi Allah sepenuh-penuhnya, tidak mengasihi yang lain, termasuk akal budi, menyimpan perkataan Allah di dalam hati, pikiran mereka harus dipenuhi dengan hukum dan ketetapan Tuhan sehingga segala percakapan dan kegiatan mereka harus dikuasai oleh firman itu.Allah adalah prioritas bagi umat Allah sebagai pusat penyembahan dan sumber kehidupan.
\end{abstract}

\section{Kata Kunci : Prinsip-prinsip Pengajaran Anak}




\section{A. PRINSIP-PRINSIP PENGAJARAN DALAM} KITAB ULANGAN

Prinsip-prinsip pengajaran dalam kitab Ulangan mencakup beberapa aspek. Berikut ini adalah pembahasannya.

\section{Dasar Pengajaran: Perintah Allah (6:1)}

Ulangan 6:1 yang berbunyi "Inilah perintah, yakni ketetapan dan peraturan, yang aku ajarkan kepadamu atas perintah Tuhan, Allahmu, untuk dilakukan di negeri, kemana kamu pergi untuk mendudukinya." Dan Ulangan 6:4-5 yang berbunyi: "Dengarlah, hai orang Israel: Tuhan itu Allah kita, Tuhan itu Esa! Kasihilah Tuhan Allahmu, dengan segenap hatimu, dan dengan segenap jiwamu, dan dengan segenap kekuatanmu." Kedua ayat ini disebut oleh Musa sebagai perintah, yakni: ketetapan dan peraturan. "Ketetapan" yang berarti "ketentuan atau kepastian" sedangkan "peraturan" yang berarti "petunjuk atau kaidah atau ketentuan." Perintah ini datangnya dari Allah. Ini berarti merupakan perintah yang sangat penting yang harus diajarkan dan dilakukan oleh umat Israel. Perintah ini sifatnya urgent, tidak dapat tidak dilakukan. Perintah ini mengandung pengajaran yang sangat penting untuk kehidupan umat Israel.

\section{Isi Pengajaran: Ketaatan (6:3)}

Secara esensi yang dikehendaki Allah dalam bagian ini ialah ketaatan umat. Adapun fondasi ketaatan ialah dengan mendengar kebenaran Allah. "Maka dengarlah, hai orang Israel! Lakukanlah itu dengan setia, supaya baik keadaanmu, dan supaya kamu menjadi sangat banyak, seperti yang dijanjikan TUHAN, Allah nenek moyangmu, kepadamu di suatu negeri yang berlimpah-limpah susu dan madunya (6:3)."

Fondasi ketaatan dimulai dengan mendengarkan - dengan mendengar Firman. Mendengar adalah perlindungan terhadap ketakutan dan pengerasan hati (Ibr. 3:7). Ayat-ayat ini ditujukan kepada bangsa Israel. Tetapi pada khususnya, ditujukan kepada orang tua terutama kepada para ayah dan para kakek oleh karena peran kepemimpinan mereka menurut Kitab Injil, dan oleh karena tanggung 
jawab para orang tua di dalam pengabadian iman pada anak-anak mereka. Hal ini jelas dari konteksnya (band. ay. 2, 7, 20).

Bagi para ayah, hal yang terpenting yang bisa dilakukan untuk diri sendiri dan keluarga adalah menjadikan pendengaran akan Firman Allah menjadi suatu prioritas yang terbesar dalam hidup secara pribadi dan dalam hidup anak-anak. Anak-anak harus mempelajari pentingnya mendengar dan mengetahui Sabda Allah secara formal dan secara informal. Mendengar, mengetahui, dan menaati Firman itu penting untuk pertumbuhan rohani dan kehidupan bersama Allah, untuk kemampuan sebagai orang tua, dan untuk kehidupan anak-anak.

Tujuan mendengar Firman adalah untuk mengenal Allah. "Dengar" dalam bahasa Ibrani adalah shema yang berarti "untuk mendengar dan memahami, atau untuk mendengar dengan sikap cerdas atau tajam artinya bisa membedakan." Mendengar Firman jangan pernah merosot ke dalam formalitas religius atau ke dalam sebuah rutinitas yang religius di mana umat sekedar memberikan 'anggukan kepada Allah,' tetapi setelah itu dengan segera melupakan Allah (band. Mzm. 50:22). Ayat tersebut akan menunjukkan, bahwa tujuan mendengar Firman dan kebenaran-Nya adalah untuk benar-benar mengenal Allah dengan intim dan secara pribadi, untuk benar-benar memahami kebenaran Alkitab sehingga menjadi arti dan tuntunan kepada hubungan yang pribadi dengan Tuhan. Sebab manusia "tidak hidup dari roti saja, tetapi oleh setiap Firman yang keluar dari mulut Allah." Dengan demikian manusia perlu untuk hidup oleh Firman Allah sehingga bisa mengenal Allah secara pribadi dan meletakkan kepercayaan di dalam-Nya.

Dengan memiliki pengenalan akan Allah baik, maka manusia akan semakin menyadari bahwa ia memiliki banyak kekurangan pengetahuan akan Allah. Dengan kerendahan hati dan sikap menyembah, manusia harus belajar untuk mengukur diri sendiri, bukan oleh pengetahuan tentang Allah, bukan oleh berapa banyak ayat yang dapat dihafalkan dalam ingatan, bukan oleh karunia-karunia atau talenta-talenta atau pelayanan, tetapi dengan keintimannya lewat berdoa, bagaimana iabergaul dengan Tuhan dalam perkataannya, dengan apa yang terus ada dalam hati, dan oleh tingkat ketaatan dalam firman sesuai dengan apa yang diketahuinya. 


\section{Tuhan Itu Allah Yang Esa (6:4-5)}

"Dengarlah, hai orang Israel: TUHAN itu Allah kita, TUHAN itu esa! Kasihilah Tuhan Allahmu dengan segenap hatimu dan dengan segenap jiwamu dan dengan segenap kekuatanmu." Bagian ini didahului oleh kata Ibrani, yaitu "Shema." "Shema" berarti "dengarlah." Shema adalah dogma fundamental dari Perjanjian Lama yang oleh Tuhan Yesus disebut sebagai yang paling penting dari semua hukum (Mrk. 12:29-30).

Perikop ini memakai bentuk tunggal yang fungsinya sebagai kata pendahuluan untuk uraian-uraian berikutnya. Oleh sebab itu, menuntut keseriusan yang penuh dari pihak pendengar. Kalimat "TUHAN itu Allah kita, TUHAN itu esa," merupakan tuntutan supaya Israel mengabdi kepada TUHAN dengan kesetiaan yang total. Sebagaimana dijelaskan di atas bahwa dalam tradisi Yudaisme, Ulangan 6:4 menjadi suatu pengakuan iman yang wajib diucapkan tiap pagi dan malam. Pengakuan ini, yang disebut "Shema."

Shema, Ulangan 6:4-9 berisi apa yang disebut sebagai "kebenaran yang pokok dari agama Israel" dan "kewajiban pokok yang ditemukan di atasnya" Kebenaran yang pokok bertalian dengan "keesaan" Allah (isi ayat. 4), yang pada akhirnya akan diperinci dalam doktrin monoteisme. Kewajiban yang pokok adalah tanggapan akan kasih yang Allah tuntut dari umat (ay. 5). Dalam isi ayat 6-9 hubungan dua tema ini dengan komunitas itu diperinci. "Perkataan ini," yaitu kitab Ulangan adalah untuk dikenal oleh setiap anggota, orang dewasa dari komunitas tersebut, dan untuk mengajar hal kerajinan kepada anakanak mereka. Tidak ada hal yang lebih penting bagi masa depan orangorang kepunyaan Allah daripada komunikasi dari "perkataan ini." ${ }^{1}$

\section{Mengasihi Allah (6:5)}

Dua dari Kitab Injil menambahkan kata "akal budi" pada "hati", "jiwa" dan "kekuatan" (Mrk. 12:30, Luk. 10:27), dan Matius 22:37 menyebut "akal budi" di tempat "kekuatan." Pengajaran pokoknya ialah bahwa orang Israel harus mengasihi Allah dengan segenap jiwa

${ }^{1}$ Christensen, Duane L, Word Biblical Commentary, vol. 6: Deuteronomy 1-11 (Dallas, Texas: Word Books, Publisher, 1998). 
raga mereka, termasuk akal budi, menyimpan perkataan Allah di dalam hati dan akal budi mereka dengan perintah untuk mengikatkannya sebagai simbol pada lengan dan dahi mereka. ${ }^{2}$ Musa mungkin mengatakan bahwa yang terakhir itu dipahami secara kiasan dan bukan secara harfiah. Orang Israel tidak diwajibkan menuliskan perintahperintah Tuhan pada ambang pintu rumah mereka, tetapi pikiran mereka yang harus dipenuhi dengan hukum dan ketetapan Tuhan sehingga segala percakapan dan kegiatan mereka harus dikuasai oleh firman itu. Apabila hal ini betul-betul terjadi, maka Israel akan mendiami Kanaan selama bertahun-tahun yang akan datang dan menikmati berkat-berkat Allah $(11: 12){ }^{3}$

Pemberian simbol pada dahi dan tangan, pada masa kini tidaklah diterapkan atau dibiasakan. Pada intinya setiap anak Tuhan haruslah memiliki hati dan pikiran yang selalu terpaut kepada Allah sebagai bentuk mengasihi Allah. Itu berarti segala eksistensi kehidupan ini hanya untuk kemuliaan Allah saja. Tetapi menuliskan perintah-perintah Tuhan pada ambang pintu rumah, dapat diterapkan pada masa kini melalui hiasan-hiasan dinding yang berisi firman Tuhan. Firman Tuhan yang dituliskan dalam hiasan-hiasan itu mengingatkan manusia kepada kebaikan dan perintah-perintah-Nya.

"Engkau harus mengasihi Yahweh Allahmu" - perintah untuk mengasihi termasuk bahasa perjanjian dari Timur Dekat Kuno. Ini juga merupakan karakteristik kiasan Bapa/ anak yang digunakan di tempat lain dalam kitab Ulangan. Perintah untuk mengasihi Allah didasarkan pada sesuatu yang dapat dijadikan teladan dari kasih utama Allah.

"Dengan segenap hatimu dan dengan semua jiwamu, dan dengan segenap kekuatanmu." Manusia dipanggil untuk mengasihi Allah dengan keseluruhan diri mereka (band. 4:9, 29; 10:12). Meskipun kata Ibrani yang berarti "hati," ini bukanlah organ/ bagian badan secara fisik seperti halnya di dalam konteks ini tetapi lebih kepada apa yang disebut sebagai pikiran. Pasangan dari " hati," dan "jiwa," menyatakan bahwa suatu perbedaan dari beberapa jenis sedang dibuat antara mental dan energi dan aktivitas secara emosional. Dalam istilah kedalaman psikologi modern, kita akan mengatakan bahwa kasih kita kepada Allah adalah untuk merangkul keseluruhan pikiran kita, kedua-duanya

${ }^{2}$ Herbert Wolf, Pengenalan Pentateukh (Malang: Penerbit Gandum Mas, 2004), hlm. 229-300.

${ }^{3}$ Ibid., hlm. 300. 
pikiran tak sadar dan yang sadar. Disiplin diri dibutuhkan dan diperlukan, dalam arti bahwa kita mengasihi Allah dengan segenap kekuatan kita. Kasih yang mencakup semua kepada Allah akan menemukan ungkapannya dalam ketaatan penuh kegembiraan kepada perintah-perintah Allah.

\section{Perintah Yang Penting (6:6)}

Ayat 6 menegaskan bahwa umat Israel (umat Allah) harus dengan serius dan sungguh-sungguh memperhatikan akan setiap perintah untuk selalu mengasihi Tuhan dengan segenap hati. Perintah ini bukanlah perintah biasa tetapi perintah yang penting dan mutlak. Melalui perintah ini Allah benar-benar menginginkan bahwa firman-Nya tersimpan di dalam hati umat-Nya. ${ }^{4}$ Di dalam hati manusia yang diperbaharui, Allah menciptakan keinginan untuk saling mengasihi dan mentaati Dia. Berulang kali Allah menekankan kepada umat-Nya mengapa pentingnya kasih yang timbul dari hati. Kasih dan pengabdian kepada Allah tidak dapat dipisahkan dari ketaatan kepada hukumhukum-Nya. Dengan demikian mengasihi Tuhan hendaknya dilakukan dengan hati yang sungguh-sungguh oleh karena hal ini sangatlah penting.

\section{Metode Pengajaran (7-9)}

\section{a. Mengajar Dengan Berulang-ulang}

"Haruslah engkau mengajarkannya berulang-ulang kepada anakanakmu," (ay. 7). Diperlukan kepedulian dan kerajinan dan bersusah payah, untuk mengajari anak-anak, secepat kemampuan mereka, di dalam pengetahuan tentang Allah, dan perintah-perintah-Nya; agar mereka mengasihi Dia, takut akan Dia, melayani, dan menyembahNya, inilah yang membawa mereka ke atas di dalam pemeliharaan dan peringatan akan Tuhan.

${ }^{4}$ Donald C. Stamps, Alkitab Penuntun Hidup Berkelimpahan, pen., Nugroho Hananiel (Malang: Gandum Mas, 2004), hlm. 285. 
Salah satu cara utama untuk mengungkapkan kasih kepada Allah ialah mempedulikan kesejahteraan rohani anak-anak dan berusaha menuntun mereka kepada hubungan yang setia dengan Allah. Pembinaan rohani anak-anak seharusnya merupakan perhatian utama semua orang tua. Orang percaya harus dengan tekun memberikan kepada anak-anaknya pendidikan yang berpusatkan Allah dimana segala sesuatu dihubungkan dengan Allah dan jalan-jalan-Nya. ${ }^{5}$

Efesus 6:4 yang berbunyi: "Dan kamu, bapa-bapa, janganlah bangkitkan amarah di dalam hati anak-anakmu, tetapi didiklah mereka di dalam ajaran dan nasihat Tuhan." Ayat ini bisa saja dapat dikatakan "engkau harus mengasah atau mempertajam mereka," Firman atau perintah-perintah-Nya; itu adalah ekspresif dari kerajinan dan pengajaran, dengan sering mengulang, dengan menanamkan pengajaran secara terus menerus ke dalam pikiran mereka, berusaha keras untuk mengarahkan mereka, sehingga mereka bisa mengerti semakin jelas.

"Dengan berulang-ulang" ayat ini menandai adanya pengajaran bukan sekali, dalam-satu waktu atau suatu usaha yang satu kali, tetapi berkelanjutan terus sepanjang waktu. Rahasia untuk belajar adalah mengulangi. ${ }^{6}$

Matthew Henry menjelaskan bahwa mereka yang mengasihi Tuhan Allah dengan diri mereka perlu melakukan apa yang mereka bisa untuk melibatkan kasih sayang anak-anak mereka kepada-Nya, dengan demikian menjaga agar pembawaan agama di dalam keluarga mereka tidak terputus. Orang tua dapat melakukan dengan beberapa cara, antara lain dengan membacakannya, sering mengulangi hal-hal ini kepada mereka, mencoba semua cara untuk menanamkan perkataan tersebut ke dalam pikiran mereka, dan membuat perkataan itu menembus ke dalam hati mereka; seperti dalam mengasah pisau, pertama-tama diasah di sisi yang satu, lalu pada pada sisi yang lainnya. Orang tua harus berhati-hati dan teliti dalam mengajar anak-anak, dan tujuannya, seperti ketika mengasah, yaitu untuk mempertajam mereka dan menanamkan kepandaian atas mereka. Orang tua harus mengajarkan perkataan-perkataan tersebut kepada anak-anak, bukan

${ }^{5}$ Stamps, Alkitab Penuntun Hidup Berkelimpahan, hlm. 285.

${ }^{6}$ J. Hampton Keathley III, Tanggung Jawab Kebapaan (Ulangan 6:1-19), hamptonk3@bible.org, 
hanya kulit luarnya saja, tetapi segalanya karena bagaimanapun semua itu berada di bawah pengawasan orang tua. ${ }^{7}$

Musa memikirkan hukumnya dengan sangat sederhana dan gampang sehingga setiap ayah mampu mengajari para putranya untuk berada di dalam hukum tersebut dan setiap ibu kepada para puterinya. Dengan demikian hal yang baik itu yang terikat dengan kita harus secara hati-hati diteruskan kepada keturunan kita, sehingga hal tersebut diabadikan.

\section{b. Mengajar Dalam Rumah}

"Dan membicarakannya apabila engkau duduk di rumahmu," Kalimat pendek ini menunjuk pada setiap kesempatan atau setiap waktu, misalnya pada waktu makan, atau pada jam santai, atau bahkan ketika mengerjakan pekerjaan di dalam rumah. Cara ini adalah cara yang dapat diterima. Setiap peluang harus diambil untuk menanamkan pengetahuan tentang hal-hal yang ilahi ke dalam pikiran anak yang lembut. Pengarahan rohani harus berpusat di rumah dan melibatkan ayah dan ibu. Pengabdian kepada Allah di dalam rumah tangga wajib dilakukan. Hal itu adalah perintah langsung dari Tuhan.

Dengan alami atau wajar, hal itu dapat dilakukan ketika kita duduk, berjalan, berbaring, dan berdiri. Dengan kata lain, kita mencari peluang mengajar oleh kata dan oleh contoh melalui aktivitas seharihari mengenai kehidupan di dalam rumah. Juga, membandingkan ayat 20 dan mengikutinya sebagai pekerjaan praktis dari hal-hal ini melalui keingin-tahuan yang alami atau wajar dari anak-anak. Rumah keluarga adalah tempat pemberian Allah yang alami untuk mengkomunikasikan dan menampilkan Sabda Allah. ${ }^{8}$

\section{c. Mengajar Dalam Perjalanan}

"Apabila engkau sedang dalam perjalanan." Dalam sebuah perjalanan yang disertai oleh anak-anak, atau ketika berekreasi, di kebun, ladang, gunung atau laut. Kesempatan tersebut dapat diambil

\footnotetext{
${ }^{7}$ Matthew Henry Commentary on the Bible. e-Sword, The Sword of the Lord with an Electronic Edge. [CD ROOM].

${ }^{8}$ Ibid.
} 
dengan melihat berbagai hasil ciptaan untuk memimpin ke dalam suatu ceramah mengenai Allah, ciptaan-Nya, sifat-Nya, kesempurnaan-Nya, dan pekerjaan-Nya, dan kewajiban setiap ciptaan-Nya untuk mengasihi, takut akan Dia, dan melayani-Nya.

\section{d. Mengajar Ketika Hendak Tidur Dan Bangun Tidur}

"Ketika engkau berbaring dan apabila engkau bangun." Pada waktu akan pergi tidur, dan bangun dari tempat tidur; waktu-waktu tersebut merupakan waktu dimana cara berdoa kepada Allah, bisa diperbaiki dengan memberikan instruksi kepada anak-anak. Ceramah yang saleh mengenai pengajaran tentang mengasihi Allah, harus dinyatakan oleh para orang tua, dengan penuh penghormatan dan kesungguhan hati, karena manfaat tidak hanya terhadap anak-anak, tetapi terhadap rumah tangga, para sahabat dan rekan-rekan di tempat kerja, atau pada saat pertemuan, atau saat menerima kunjungan, dan ketika berjalan-jalan/rekreasi, atau dalam percakapan, di dalam perjalanan-perjalanan, ketika beristirahat dari segala pekerjaan rumah untuk berbaring tidur, dan ketika pagi-pagi engkau bangun dan kembali kepada keluarga. Ambil semua kesempatan untuk bercakap-cakap dengan anak tentang hal-hal yang ilahi, bukan tentang misteri-misteri yang tidak jelas, atau hal-hal yang diperdebatan secara ragu-ragu, tetapi dari kebenaran-kebenaran dan hukum yang jelas dari Allah, dan hal-hal yang memberi kita damai sejahtera." Sebab semakin kita mempercakapkannya di antara kita semakin kita akan mengaguminya dan terpengaruh dengannya.

\section{e. Mengikatkan Sebagai Tanda Di Tangan Dan Lambang Di Dahi}

"Haruslah juga engkau mengikatkannya sebagai tanda pada tanganmu," Sebagai seorang manusia yang mengikatkan sesuatu pada tangannya sebagai suatu tanda, di mana ia mungkin mengingat sesuatu yang ia rindukan; meskipun demikian Bangsa Yahudi memahami hal ini secara harfiah, tentang mengikat sebuah gulungan kertas perkamen, pada bagian ujung yang satu dan yang lainnya sedangkan tulisannya ditulis di dalamnya, di atas tangan kiri mereka.

"Dan haruslah itu menjadi lambang di dahimu," dimana rumbairumbai, yang dipakai oleh bangsa Yahudi di atas dahi mereka, dan di 
tangannya. Ulangan 6:8, 9, kemungkinan bahwa pada waktu itu ada sedikit atau beberapa salinan yang tertulis dari keseluruhan hukum. Hanya di pesta tabernakel hukum tersebut dibacakan kepada mereka; dan oleh karena itu Allah menetapkan mereka untuk menulis sebagian kalimat yang dipilih dari hukum, yang paling penting dan menyeluruh, di atas dinding mereka, atau di gulungan-gulungan dari kertas perkamen yang dikenakan di sekitar pergelangan tangan mereka, dan karenanya sebagian orang berpikir rumbai-rumbai yang sangat banyak digunakan di antara orang Yahudi.

Kristus menyalahkan orang-orang Farisi, bukan karena mereka memakai, tetapi karena motivasi pemakaian mereka untuk lebih pandai dibanding orang lain, (Mat. 23:5). Dengan bijaksana dan dengan penuh iman disediakan oleh pembaharu-pembaharu yang pertama gereja Inggris, yang kemudian, ketika Alkitab menjadi langka, sebagian orang memilih bagian kitab suci yang harus ditulis di tembok dan tiang-tiang gereja, yang mana akan membuat orang-orang familiar dengannya. Kita perlu mencoba dengan segala cara yang tentu saja untuk membuat Firman Allah dikenal baik bagi kita, yaitu bahwa kita telah menyiapkannya untuk semua kesempatan, untuk pengekangan kita dari dosa dan arah dan kegembiraan kita. Ia harus seperti yang terukir di telapak tangan kita, selalu berada di depan mata kita.

Ini juga mengisyaratkan bahwa kita jangan pernah malu untuk memiliki agama kita, maupun untuk memiliki diri kita sendiri di bawah pengawasan dan pemerintahan olehnya. Biarlah itu tertulis di gerbanggerbang kita, dan membiarkan semua yang lewat pintu kita membacanya, bahwa kita percaya Yahweh untuk menjadi Allah saja, dan percaya diri kita sendiri harus mengasihi Dia dengan segenap hati kita.

\section{f. Menulis Pada Tiang Pintu Rumah Dan Pintu Gerbang}

"Dan haruslah engkau menuliskannya pada tiang pintu rumahmu dan pada pintu gerbangmu." Untuk mengingatkan kepada mereka ketika mereka ke luar dan masuk ke dalam, sehingga mereka bisa berhati-hati untuk mematuhinya. Bangsa Yahudi memahami ini secara harfiah juga, dan menuliskan bagian ini dalam sebuah gulungan kertas perkamen dengan beberapa kutipan teks pendek, dan di sini Targum Yonathan, memperbaikinya ditiga tempat, berhadapan dengan kamar 
tempat tidur, di atas tiang- tiang rumah, dan di gerbang sebelah kanan; dan inilah yang mereka sebut Mezuzah; dan inilah nama yang diberikan baginya. Kertas perkamen disediakan untuk tujuan, mereka menulis kata-kata di Ulangan 6:4 dan kemudian menggulungnya kertas perkamen ke atas, dan menulis di atasnya "Shaddai," dan menaruhnya dalam rotan atau alang-alang, jika tidak ke dalam bagian kayu yang berongga, dan mengikatkannya pada tembok di tiang-tiang pintu di sebelah kanan dari pintu masuk; dan dengan seperti itu, setiap kali mereka keluar masuk, mereka menjadikannya sebagai bagian dari pengabdian mereka untuk menjamah kertas perkamen ini, dan menciumnya.

Fokus dalam mengajar anak-anak anda "perkataan-perkataan ini" dengan rajin dalam konteks keluarga pada waktu dan tempat yang dapat dipikirkan, menjelaskan sekali lagi tujuan yang bersifat pendidikan dari kitab Ulangan. Isi dari kitab ini adalah kurikulum yang utama dalam satu program yang berkelanjutan dari pendidikan yang religius pada bangsa Israel di masa lampau. Pemakaian rumbai-rumbai dan mezuzoth merupakan perkakas yang bersifat pendidikan yang sangat utama, yang dirancang untuk menjaga agar pernyataanpernyataan ringkasan yang besar dari "perkataan-perkataan Yahweh" menjadi pokok dalam pengalaman tiap anggota individu komunitas perjanjian. ${ }^{9}$

\section{Tujuan Pengajaran (6:12-15)}

\section{a. Agar Tidak Melupakan Tuhan (12)}

Kebaikan-kebaikan Allah merupakan dasar bagi umat untuk tidak melupakan Tuhan. Bangsa Israel diminta untuk merenungkan perjalanan mereka yang penuh liku-liku, akan tetapi penyertaan Tuhan begitu nyata bagi mereka. Berkat-berkat Tuhan yang melimpah yang menantikan mereka harus menjadi dasar bagi mereka untuk selalu mengingat penyertaan Tuhan yang luar biasa.

Demikianpun bagi para orang tua yang dengan rajin dan setia memberi pengajaran kepada anak mengenai kebaikan-kebaikan Tuhan, akan menolong anak untuk mengerti dan mengingat bagaimana Tuhan

${ }^{9}$ Duane, Word Biblical, 1998. 
menolong mereka dalam hidup keseharian dan dalam keluarga masingmasing. Menolong anak untuk menyadari dan merasakan bahwa sungguh-sungguh Allah telah turut campur tangan dalam kehidupan anak itu sendiri dan keluarganya. Secara khusus anak dapat mengucap syukur atas keselamatan yang telah mereka miliki.

\section{b. Agar Takut Kepada Allah (13)}

Tujuan dari pengarahan oleh orang tua ialah mengajar anak-anak untuk takut akan Tuhan, berjalan pada jalan-Nya, mengasihi dan menghargai Dia, serta melayani Dia dengan segenap hati dan jiwa. Pengalaman di Horeb dalam Ulangan 4 dirancang untuk menghasilkan sebuah pemujaan yang takut Allah dalam hati manusia sehingga perjanjian antara mereka dan Allah menjadi mungkin. Dalam Perjanjian Lama takut akan Allah lebih dari perasaan kagum atau penghormatan, meskipun demikian kedua-duanya termasuk di dalamnya. Takut akan Allah berarti menjadi benar-benar mengetahui dan memahami tentang kemurnian moral dan kemahakuasaan-Nya sehingga manusia benarbenar takut untuk menentang-Nya. Takut akan Allah juga termasuk menanggapi-Nya dalam penyembahan, pelayanan, kepercayaan, ketaatan, dan komitmen.

Takut akan Tuhan dalam implikasi setiap pribadi manusia adalah sebagai berikut: jika manusia sungguh-sungguh hidup takut akan Tuhan, maka manusia akan hidup taat kepada perintah-perintah-Nya dan dengan tegas menampik dosa. Suatu akibat wajar yang penting dari implikasi tersebut adalah oorang percaya harus mengajar kepada anakanak untuk takut akan Tuhan dengan membina mereka untuk membenci dosa dan taat kepada perintah-perintah Allah yang kudus (6:1-2, 6-9).

Karena sasaran dasar dari pengajaran anak ialah agar mereka hidup sesuai dengan prinsip-prinsip hikmat Allah, mengajar mereka untuk hidup takut kepada Tuhan merupakan suatu langkah pertama yang sangat penting dan baik. Takut akan Tuhan membuat kita membenci dosa dan menjauhkan diri dari kejahatan. Takut akan Tuhan menyebabkan seseorang lebih berhati-hati dan menahan diri dalam pembicaraan, juga melindungi diri dari keruntuhan hati nurani. Takut akan Tuhan itu murni dan menyucikan, kudus dan mempunyai pengaruh yang menyelamatkan, juga mendorong umat Allah untuk 
menyembah Dia dengan segenap dirinya. Allah sudah berjanji untuk memberikan pahala kepada semua orang yang takut akan Tuhan. Ganjaran kerendahan hati dan takut akan Tuhan ialah kekayaan, kehormatan, dan kehidupan (Ams. 22:4). Orang yang takut akan Tuhan mengetahui bahwa mereka akan memperoleh kebahagiaan, apapun yang terjadi di sekitarnya. ${ }^{10}$

\section{c. Agar Beribadah Kepada Allah (14)}

Anak-anak yang sudah memiliki hubungan yang dekat dengan Allah dan mengerti akan kasih Allah bahkan pernah mengalami kasih Allah pasti di dalam hatinya memiliki kerinduan untuk beribadah. Pengalaman yang menyenangkan bertemu dengan Tuhan dalam satu titik pertemuan yang indah membawa anak-anak kepada takut akan Tuhan dan kerinduan untuk dekat dengan Tuhan. Kerinduan untuk dekat dengan Tuhan merupakan modal utama untuk anak-anak senang beribadah. Ibadah yang menarik dan tidak membosankan merupakan hal yang sangat baik untuk tmembawa mereka dalam acara pertemuan antara anak dengan Tuhannya.

Anak mungkin belum memahami betul akan arti ibadah yang sesungguhnya. Tetapi kesenangan untuk menghadiri kebaktian anak ataupun sekolah minggu ataupaun acara-acara gereja yang lain, menolong mereka. Ibadah adalah hubungan dengan Tuhan. Hubungan yang harmonis dengan Tuhan haruslah nyata dalam hubungan yang harmonis dengan sesama manusia, sebab itu adalah cerminan bagi hubungan yang baik dengan Tuhan.

Ibadah berpusat kepada Allah dan bukan kepada manusia. Dalam ibadah Kristen, kita menghampiri Allah dengan bersyukur karena apa yang telah dilakukan-Nya bagi kita di dalam Kristus dan melalui Roh Kudus. Ibadah menuntut iman dan pengakuan bahwa Dialah Allah dan Tuhan kita. Bagi anak-anak, kemungkinan kesadaran ini belumlah dimilikinya tetapi paling tidak anak-anak memiliki kesukaan untuk dekat dengan Tuhan dalam ibadah itu.

Dua prinsip pokok yang menentukan ibadah Kristen ialah penyembahan yang sesungguhnya yang terjadi dalam roh dan kebenaran (Yoh. 4:23). Maksudnya adalah penyembahan harus

\footnotetext{
${ }^{10}$ Stamps, Alkitab Penuntun Hidup Berkelimpahan, hlm. 286-287.
} 
dilakukan sesuai dengan penyataan diri Allah didalam putera-Nya. Demikian pula, ibadah melibatkan roh manusia dan bukan hanya pikirannya. Ciri utama ibadah PL adalah sistem persembahan korban. Karena korban Kristus disalib menggenapi sistem ini, didalam ibadah Kristen tidak perlu pencurahan darah lagi. Melalui sakramen Perjamuan Kudus, gereja PB terus menerus memperingati korban yang satu kali untuk selama-lamanya (1 Kor. 11:23-26). Demikian pula, gereja dinasehatkan untuk "senantiasa mempersembahkan korban syukur kepada Allah, yaitu ucapan bibir yang memuliakan nama-Nya" (Ibr. 13:15) dan untuk mempersembahkan tubuh kita sebagai "satu persembahan yang hidup, yang kudus, dan yang berkenan kepada Allah." (Rm. 12:1). ${ }^{11}$

Ucapan bibir yang memuliakan Allah adalah puji-pujian kepada Allah. Pujian adalah unsur penting dalam ibadah Kristen, sebab didalam pujian umat Tuhan bisa memuji Allah, menyembah Dia dan mengucap syukur atas kebaikan-kebaikan-Nya. Satu cara penting untuk memuji Allah ialah dengan menyanyikan mazmur, kidung puji-pujian dan nyanyian rohani.

Aplikasi bagi anak-anak mengenai ibadah ialah anak-anak dapat diajar untuk menyembah dan mengucap syukur kepada Allah melalui puji-pujian. Semua anak senang untuk memuji Tuhan melalui nyanyian. Lagu-lagu dan musik dapat menarik anak-anak untuk datang kepada Tuhan. Porsi dalam ibadah anak atau Sekolah Minggu harus penuh dengan pujian, sebab puji-pujian itu akan membawa anak kepada firman Allah dan dalam doa. Puji-pujian mempersiapkan anak untuk menerima kebenaran firman Allah.

Musa mengingatkan agar mereka jangan beribadah kepada allah lain. Allah secara tegas dan jelas melarang bangsa itu untuk terlibat dengan salah satu dewa berhala di Kanaan. Dia sungguh-sungguh akan cemburu mempertahankan kehormatan akan nama-Nya. ${ }^{12}$ Allah menghendaki kekudusan hidup dari umat Allah. Dan umat-Nya harus hanya menyembah Dia saja.

\footnotetext{
${ }^{11}$ Stamps, Alkitab Penuntun Hidup Berkelimpahan, hlm. 728.

${ }^{12}$ Meredith G. Kline, The Wycliffe Bible Commentary, vol. 1 (Malang: Gandum Mas, 2004), hlm. 453.
} 


\section{Dampak Pengajaran (18-19)}

Bila pengajaran dilaksanakan dengan benar, pasti ada dampak yang sangat baik bagi kehidupan anak. Tentu saja dampak pengajaran akan menghasilkan hidup yang diberkati. Kebaikan dan berkat adalah akibat dari melakukan apa yang benar dimata Tuhan.

Kepercayaan kita yang tulus dan murni kepada Tuhan dengan tidak memiliki allah yang lain dan hanya menyembah Dia saja membuktikan murninya penyembahan kita. Allah yang esa menghendaki yang demikian dari umat-Nya. Umat Allah harus tetap berpegang pada perintah, peringatan dan ketetapan Tuhan yang sudah diperintahkan untuk ditaati.

Perintah untuk mengasihi Tuhan dengan segenap hati, dengan segenap jiwa dan dengan segenap kekuatan, bila dengan rajin dan tekun dan terus menerus diajarkan kepada anak, akan menjadi pola bagi anak untuk tetap mengasihi Tuhan. Sekalipun dalam menjalani hidupnya dan dalam mencari jati dirinya, anak-anak harus jatuh bangun dalam menemukan dirinya sendiri di hadapan Allah. Akan tetapi pola mengasihi Tuhan sudah ada di dalam hatinya. Dengan demikian berkatberkat Tuhan sudah mengikutinya.

Ayat 18-19 mencatat berkat-berkat yang menyertai orang-orang yang melakukan apa yang benar dan baik di mata Tuhan. Berkat pertama adalah, "supaya baik keadaanmu." Kehidupan anak-anak Tuhan, selalu ada dalam keadaan yang baik. Belum pernah ada anak Tuhan yang hidup mengasihi Tuhan dan melakukan kebenaran dan kemudian hidupnya kacau balau. Tentu ini tidak cocok dengan kebenaran firman. Anak Tuhan hidupnya tertib dan teratur, tidak kacau balau. Berkat kedua adalah "engkau memasuki dan menduduki negeri yang baik." Negeri yang baik adalah tanah perjanjian yang sudah disiapkan Tuhan bagi bangsa Israel. Disana dikatakan berlimpahlimpah susu dan madunya.

Suatu hidup yang penuh keberkatan. Anak-anak Tuhan bisa menikmati segala berkat dari Tuhan, kadang-kadang berkat itu tanpa disangka-sangka dan Tuhan telah mempersiapkannya bagi anak-anak yang takut akan Dia. Berkat ketiga adalah Tuhan mengusir semua musuh. Anak Tuhan cinta akan perdamaian, sehingga satu orang musuh sudah terlalu banyak bagi seorang anak Tuhan. Itu berarti anak Tuhan akan gelisah dan tidak tenang ketika ada persoalan yang tidak diselesaikan, sehingga mendorong dia untuk menyelesaikan dengan 
orang lain. Hal inilah yang medasari hati setiap anak-anak Tuhan untuk selalu menciptakan kedamaian. Bahkan ketika berada dalam situasi yang sulit dan tertekan, ia harus tetap tenang, meyakini bahwa dalam segala hal Allah sanggup menolong dan melimpahkan segala berkatberkatNya.

\section{B. KESIMPULAN}

Prinsip-prinsip pengajaran yang diajarkan oleh Allah kepada umat Israel mendatangkan kebahagiaan dan berkat-berkat bagi umat Allah itu. Pengakuan akan keesaan Allah dinyatakan dalam ketaatan kepada kebenaran dalam hidup sehari-hari. Memiliki hidup yang mengasihi Allah, akal budinya diserahkan kepada Allah. Ini merupakan suatu pola kehidupan yang sangat baik dalam membawa anak-anak dekat dengan Allahnya sekaligus menjadi suatu pola kehidupan pada masa dewasa. Akan menjadi orang dewasa yang takut akan Allah. Pola ini diperkenalkan oleh orang tua dan gereja sejak anak-anak masih kecil atau sedini mungkin setiap anak diperkenalkan kepada Juruselamat.

\section{DAFTAR PUSTAKA}

Duane L, Christensen. Word Biblical Commentary, vol. 6: Deuteronomy 1-11. Dallas, Texas: Word Books, Publisher, 1998.

Henry, Matthew. Commentary on the Bible. e-Sword, The Sword of the Lord with an Electronic Edge. [CD ROOM]

Keathley III, J. Hampton. Tanggung Jawab Kebapaan. Ulangan 6:1-19. hamptonk3@bible.org.

Kline, Meredith G. The Wycliffe Bible Commentary, Vol. 1. Malang: Gandum Mas, 2004.

Stamps, Donald C. Alkitab Penuntun Hidup Berkelimpahan. Diterjemahkan oleh Nugroho Hananiel. Malang: Gandum Mas, 2004.

Wolf, Herbert. Pengenalan Pentateukh. Malang: Gandum Mas, 2004. 